\title{
РОЗВІДУВАЛЬНА, КОНТРРОЗВІДУВАЛЬНА Й АГЕНТУРНА ДІЯЛЬНІСТЬ РІВНЕНСЬКИХ РАДЯНСЬКИХ ПАРТИЗАНСЬКИХ З’ЄДНАНЬ У БОРОТЬБІ $З$ ОУН(Б) І УПА (1943-1944рp.)
}

У статті на основі архівних матеріалів вперше комплексно розглянуто питання розвідувальної, контррозвідувальної й агентурної діяльності партизанських з'еднань, які підпорядковувалися Рівненському обласному штабу партизанського руху у боротьбі з українським повстансько-підпільним рухом на Волині. Проаналізована агентурно-розвідувальна робота опергрупи НКДБ УРСР «Розгром», яка восени 1943 р. прибула до Рівненського партизанського з'єднання № 1. Показано, що українські повстанщі також намагалися створити агентурні позиції у рівненських радянських партизанських з'еднаннях.

Ключові слова: ОУН, УПА, УШПР, РПЗ № 1, РПЗ № 2, опергрупа НКДБ УРСР «Розгром», розвідка, агентура, радянські партизани, українські повстанщі.

Постановка проблеми. Розвідувальна, контррозвідувальна й агентурна діяльність відіграє важливу роль у попередженні та відсічі діяльності ворожих спецслужб, спрямованої на розкладання, дезорганізацію громадських і державних організацій, здобуття стратегічної інформації чи проведення ліквідаційно-терористичних актів. Крім того, потенціал даної роботи полягає і в тому, що завдяки їй можна створити агентурні позиції у середовищі противника та здобути важливі розвідувальні дані.

Вивчення досвіду «таємного фрронту війни» і протистояння спецслужб не втрачає актуальності сьогодні, оскільки сучасні держави активно використовують розвідувальні та контррозвідувальні органи для забезпечення захисту й здобуття необхідних розвідувальних даних. Разом з тим, діяльність останніх при цілеспрямованій агресивній політиці держави приймає неконвенційний (гібридний) характер.

Сухих Андрій Юрійович, аспірант кафедри історії імені М.П. Ковальського, Національний університет «Острозька академія», м. Острог.

Стаття написана завдяки гранту Наукового Товариства ім. Шевченка в Америці (НТШ-А)

() Сухих А.Ю., 2017 
Аналіз попередніх досліджень. У радянській історіографії питання діяльності партизанської розвідки на терені України спеціально вивчали Г. Міщенко та Г. Мігрін. Проте, у своїй колективній монографії вони висвітлили лише використання червоними партизанами розвідки у боротьбі із німецькими окупантами [23]. Основні напрямки, результати й організацію партизанської розвідки вивчали I. Курас та А. Кентій [22].

Попри велику кількість досліджень про український повстансько-підпільний і радянський партизанський рухи, які з'явилися за незалежної України, питання використання розвідувально-агентурного апарату останніми у взаємній боротьбі на грунтовному рівні вивчали лише кілька дослідників, що, перш за все, пояснюеться складністю пошуку матеріалів і тривалою відсутністю доступу до документів радянських карально-репресивних органів. Серед науковців, які торкалися ціеї теми варто згадати Я. Антонюка, Г. Биструхіна, Д. Веденєева, А. Кентія, В. Лозицького, В. Сергійчука та В. Трофримовича.

Мета статті - проаналізувати протиповстанський аспект розвідувальної, контррозвідувальної й агентурної діяльності радянських партизанських з'єднань, які підпорядковувалися Ровенському* обласному штабу партизанського руху під час німецької окупацї. Це, зокрема, Ровенське партизанське з'єднання № 1 (далі - РПЗ № 1), Ровенське партизанське з'єднання № 2 «За Батьківщину» (далі РПЗ № 2) та Ровенське партизанське з'єднання ім. Щорса (далі - РПЗ ім. Щорса). Принагідно зазначимо, що матеріали стосовно згаданої діяльності відсутні про Ровенське партизанське з'єднання № 3 (польське).

Виклад основного матеріалу. 3 перших днів німецькорадянської війни партизанські загони потребували налагодження розвідувального та контррозвідувального забезпечення. По-перше, у цьому була необхідність, оскільки розвідувальні данні здобуті у прифронтових зонах та в глибокому тилу могли бути використанні Народним

* У статті використовуеться найменування часів УРСР. 
комісаріатом внутрішніх справ, Центральним штабом партизанського руху (далі - ЦШПР) і Українським штабом партизанського руху (далі - УШПР) при стратегічному плануванні дій партизанських з'єднань, а також Червоною армією (далі - ЧА) під час фронтових наступальних операцій. По-друге, контррозвідка повинна була забезпечити захист від заходів спецслужб противника у створенні в партизанських формуваннях власних агентурних позицій, а також зриву планів радянських партизанів із дезорганізацї тилу німецьких військ.

Одним із перших кроків у формуванні розвідки та контррозвідки партизанського руху варто вважати розпорядження ЦШПР від 14 липня 1942 р. про поліпшення розвідувальної діяльності партизанів України, де центральний штаб пропонував ввести в партизанських загонах посади заступників командира із військової й агентурної розвідки, виділивши для цієї роботи спещіальні групи партизанів; започаткувати практику засилання в тил ворога спеціальних розвідувальних партизанських загонів і груп із засобами радіозв'язку [20, с. 251].

Відповідно до наказу Державного комітету оборони CРCP № 00189 від 5 вересня 1942 р. «Про завдання партизанського руху», закликалося вести безперервну розвідувальну діяльність в інтересах ЧА. Передбачалося, що, створені у партизанських загонах оперативні частини повинні були вести військову й агентурну розвідку, а також займатися контррозвідувальною роботою. Конкретизувалося, що основними напрямами розвідувальної діяльності партизанів мали стати військові, адміністративні та промислові об'єкти німецьких окупантів [24, с. 210-211].

Згідно 3 наказом Ставки Верховного Головнокомандувача № 0073 від 19 квітня 1943 р., розвідувальний апарат партизанів мав бути посилений кадрами органів держбезпеки. Документ передбачав запровадження в партизанських з'єднаннях посад заступників командирів із розвідки. УШПР підкреслював, що розвідка визначалася не лише завданнями партизанів, а й інтересами командування ЧА [7, с. 328-329]. 
Заходи із формування оперативних частин партизаньких з'еднань були завершені весною 1943 р., однак уніфікації розвідувального апарату не вдалося досягти. Розвідувальна діяльність партизанів трималася на заступниках командирів із розвідки, які були практично у кожному партизанському з'єднанні. Оперативні частини, іiї структура та штати не були однакові. Різними були й склад підрозділів, які виконували бойову розвідку [22, с. 174]. Наприклад, у Житомирському партизанському з'еднанні оперативна частина керувала розвідувальною діяльністю, маючи в своему розпорядженні взвод розвідників, а у загонах - спеціальні розвідувальні групи. У Чернігівсько-Волинському партизанському з'еднанні загальне керівництво розвідувальною діяльністю здійснював заступник командира з розвідки, який мав кількох помічників - начальника 3 військової розвідки й особового відділу, двох політруків і командира взводу розвідки [20, с. 254-255]. Разом із тим, партизанська розвідувальна служба, що складалася із системи спеціальних органів, забезпечувала необхідною інформацією партизанські формування та командування ЧА [20, с. 256; 22, c. 174].

Потреба використання червоними партизанами розвідки, контррозвідки й агентури у боротьбі з українськими націоналістами особливо стала актуальною, коли відносини між ними перейшли до взаємного протиборства. Разом із тим, ОУН та УПА, які ставили за мету створити самостійну українську державу, завжди залишалися ворогом Радянського Союзу з ідеологічних і політичних міркувань, тому ліквідація українських націоналістів була пріоритетним завданням радянських карально-репресивних органів. Певний опосередкований вплив на активізащію ціеї роботи зіграв фрактор розгрому гітлерівських військ у битві під Сталінградом на початку лютого 1943 р., після чого УШПР і підпорядковані йому партизани, поступово активізували дії щодо дезорганізащії ворожого тилу та розгортання контрольованого більшовиками руху Опору, у теренах, які не були ним охоплені. Аспектом цього стала компрометація та ліквідація ОУН і УПА, які в силу захисту місцевого 
населення від ворожих акцій і боротьби із «московським імперіалізмом», ставали на заваді червоним партизанам реалізувати їхні військові плани на Волині. Особливістю протистояння між радянськими партизанами й українським повстансько-підпільним рухом була боротьба останніх на «таємному фрронті війни».

Однією зі стратегічних цілей розвідки партизанів був збір інформації про українських націоналістів. Перш за все вона поділялася на бойову й агентурну. Перша передбачала діяльність кінних чи піших груп у районах, які цікавили командування з'єднань і загонів. Залежно від району кількість розвідників складала 5-30 осіб і більше. Кінна розвідка була в кожному загоні та штабі з'єднання i діяла у радіусі від 10 до 40 км. Перед початком роботи вона отримувала від командира загону конкретне завдання. Результати у вигляді рапорту надходили до командира з'єднання. На випадок планування масштабної бойової операції, проводилася довготривала розвідка із залученням різних груп, аби мати можливість перевірити точність даних із декількох джерел [34, арк. 18].

У період загострення протистояння радянських партизанів з українськими повстанцями на початку листопада 1943 р. заступник начальника УШПР С. Бельченко та начальник розвідувального відділу М. Анісімов надіслали до партизанських з'єднань директиву № 3762, де вимагалося виявляти й брати на облік націоналістичні відділи, створювати в них агентуру, через яку з'ясовувати чисельність, структуру, склад повстанських загонів і стосунки 3 німцями [6, с. 293]. Розвідники для глибокої розвідки (агентури) серед українських повстанців підбиралися 3 місцевих партизанів, які добре знали українську мову та місцевість. Під «маркою націоналістів» вони вирушали у терени, підконтрольні УПА. Таким чином їм вдалося дізнатися про місце перебування штабу упівських відділів «Лайдаки» та «Кори»і продовольчих складів у районі с. Кідри та Осова Дубровицького району, якими вони заволоділи під час операції на початку січня 1944 р. [30, арк. 19, 23]. 
Агентура серед українських повстанців також формувалася безпосередньо з учасників націоналістичного руху, які попередньо вивчалися і вербувалися. Так, вона була у відділах «Лайдаки», «Кори» та «Яреми», які діяли на Рівненщині [16, арк. 20]. 3 цього приводу заступник командира з розвідки РПЗ № 1 В. Тимофеєв згадував: «Ми мали досить сильну агентуру в керівництві [повстанських відділів], розкладали їх шляхом поширення нашої літератури, а в крайньому випадку, коли ця міра була малодієвою, ми через агентуру встановлювали місце розташування [повстанського] з'єднання і збройною силою розбивали наголову » [38, арк. 103].

Агентуру очолював резидент, контакт із яким встановлювався через зв'язкових, які ним же надсилалися. У дуже рідких випадках відбувалося навпаки. Крім того, діяла мережа інформаторів, які мали зв'язок із червоними партизанами майже у кожному селі на півночі Рівненщині [13, арк. 56]. «Підбирали людей приблизно так: зайдеш в одне село, з однією людиною зустрінешся, поговориш, у результаті розмови виявиш, хто може принести користь, якщо дати йому завдання, - розповідав В. Тимофеєв про систему підбору кадрів для партизанської розвідки та агентури, - далі ведеш із ним дипломатичні переговори та доходиш до того, що потрібно. Даеш завдання. З'ясовуеш осіб, у яких є родичі, далекі та близькі, у розташуванні противника, створюєш легенди, тоді даєш завдання [...]. Коли вони повертаються, поговориш із ними, співставляеш їх відомості та в результаті створюеться відповідна думка» [37, арк. 2].

Аби розширити агентурно-розвідувальну діяльність у націоналістичному підпіллі та повстанських відділах, які діяли на Рівненщині, 7 жовтня 1943 р. у з'єднання В. Бегми прибула група 4-го управління НКДБ УРСР «Розгром» (4 оперпрацівники та 2 радисти) на чолі з капітаном Г. Бурлаченком («Петровим») [25, с. 234 ; 20, с. 273]. Примітним е той факт, що їі члени 8 грудня були призначені помічниками командирів партизанських загонів з розвідки 
[10, арк. 15-18; 11, арк. 13-14; 31, арк. 51]. Зокрема, лейтенант С. Ткаченко («Остап») вступив на зазначену посаду у загін ім. Ворошилова, лейтенант П. Буцан («Меч») загін ім. Шевченка, А. Голубев («Малий») - загін ім. Берія, а капітан Г. Бурлаченко став замісником командира РПЗ № 1 В. Бегми з оперативної частини [9, арк. 78].

Агентурна схема розвідки РПЗ № 1 була підконтрольна заступнику командира з розвідки, а у загонах - оперативним працівникам та чекістам з опергрупи «Розгром». Наприклад, у процесі розбудови розвідувальної діяльності загону ім. Ворошилова лейтенант НКДБ УРСР С. Ткаченко отримав у своє розпорядження 45 кіннотників-автоматників, які надали можливість останньому проводити не лише розвідувальні, а й бойові дії [10, арк. 15 зв.]. Отримані ж дані бойової й агентурної розвідок надходили в оперативну частину з'єднання, де робилися відповідні висновки, що слугували основою для проведення операцій [13, арк. 18].

Загалом за час перебування чекістської опергрупи в тилу противника було завербовано для розробки українського націоналістичного підпілля 16 агентів, польського - 4. Виявлено і взято на облік 932 учасники ОУН і УПА та ї симпатиків, а також здобута націоналістична література [5, с. 182; 25, с. 237]. Крім цього, серед результатів агентурно-розвідувальної діяльності опергрупи «Розгром» на Рівненщині варто відзначити, по-перше, знищення мережі зв'язку оунівців у с. Кідри, Озеро, Хіночі, Степангород і Біле, а також куща ОУН у с. Млинок на чолі з О. Веремчук («Вербою»); по-друге, розкладення агентурними діями відділу самооборони, що діяв у районі с. Степангород [10, арк. 17-18]; по-трете, здобуття даних про дислокацію упівських відділів «Лайдаки» та «Кори» у районі с. Кідри, завдяки чому було організовано протиповстанські операції 2325 грудня 1943 р. і 4-8 січня 1944 р. [9, арк. 80 ; 26, с. 146-147].

Разом із тим результати діяльності опергрупи «Розгром» були мінімальними, оскільки чекістам вдавалося знищити лише кілька осередків оунівського підпілля. Недоліки ж у роботі опергрупи виникли внаслідок відсутньої сталої 
дислокації РПЗ № 1 та його перебування в лісистій місцевості, де був відсутній контингент для розвідувальної роботи, а також незнання всіма чекістами української мови на високому рівні. Складність створення агентури виявлялася й через те, що більшість місцевих жителів були малоосвіченими. Крім того, траплялися випадки, що завербовані агенти не дотримувалися правил конспіращії, через що були виявлені та страчені бандерівцями. Наприклад, націоналісти розкрили та повісили агента «яора» (Шимшель Гаврило, житель с. Каноничі Володимирецького району) [12, арк. 10].

Своєю чергою, як випливає із документів оперативного відділу партизанських загонів Рівненської області, їхній особовий склад у зв'язку з загостренням протистоянням 3 упівцями без жалю розстрілював полонених, не переймаючись міжнародними конвенціями [15, арк. 21, 46, 47, 55, 57, 82, 83, 86, 90, 93, 102, 103; 32, арк. 5 та зв.]. Варто згадати, що так ліквідували районного провідника Висоцького проводу ОУН Андрія Соловея, якого 21 травня 1943 р. у с. Людинь захопили в полон, де й стратили [14, арк. 41, 47;18, арк. 64].

Згідно з наказом № 16 від 8 березня 1943 р. по РПЗ № 2, командирам загонів дозволялося здійснювати розстріли поліцейських і націоналістів без «оформлення», лише у складних ситуаціях і під час бойових операцій. Тому затриманих осіб, зазвичай, доправляли до начальника оперативної частини М. Корчева, який і вирішував їхню долю [14, арк. 22].

Очищення теренів від нащіоналістів також було метою діяльності опергрупи капітана Г. Бурлаченка («Петрова»). Наприклад, 28-29 грудня 1943 р. унаслідок операції в районі с. Золоте та Озеро Володимирецького району було захоплено в полон 30 бандерівців, яких «за лінією оперативних заходів» розстріляли чекісти. Останні ж підірвали також 5 націоналістичних пам'ятників у тих селах [32, арк. 101]. Значний внесок у «позитивні» результати рейду радянських партизанів Володимиреччиною та Дубровиччиною, який відбувався 
у перший тиждень січня 1944 р., також зробила зазначена опергрупа НКДБ УРСР. Вона на основі агентурних даних, розстріляла 57 «активних українських націоналістів та їх симпатиків» у с. Каноничі, Дубівка, Кідри та Осова [35, арк. 61].

Крім націоналістів жертвами партизанів ставали місцеві жителі, яких вбивали за найменші нарікання чи скарги на діяльність «народних месників». Для прикладу, Я. Полюховича із х. Осовці Висоцького району 4 липня 1943 р. розстріляли за те, що він був «антирадянські налаштованою особистістю, систематично висловлював антирадянські судження, [...] зводив наклеп на партизанів, називаючи їх бандою» [15, арк. 92]. Вища міра покарання також присуджувалась і родичам упівців. Про це можна судити із постанови про розстріл жителя с. Сохи, 73 - літнього С. Попока, якого визнали націоналістом на основі того, що його син був в УПА [33, арк. 3-4].

Конкретні фракти діяльності агентури радянських партизанів в українському повстанському русі свідчать, що вона виконала свої завдання. Наприклад, на основі їі даних були складені списки оунівців та їх спільників у 36 селах півночі Рівненщини, які загалом нараховували 654 особи [15, арк. 36-40, 59-69; 29, арк. 3 та зв.]. Їй вдалося також виявити підпільну оунівську мережу у Висоцькому районі «Нива», встановивши криптоніми населених пунктів, а також 39 підпільників. Таким чином, у повстанський район «Нива» входили такі населені пункти: Висоџьк («Млинок»), Бродець («Переходичі»), Смородськ («Буковина»), Вичівка («Береза»), Бутове («Острів», 12 осіб), Олександрове («Листок»), Річиці («Липнів», комендант - Адам Бруцький, 17 осіб), Тумень («Верби», 1 особа), Золоте («Ясиново», 3 особи), Людинь («фора», 4 особи), Рудня («Вовочиця»), Заморочення («Калуга», 2 особи), Городище («Критин») [15, арк. 73-74]. Зауважимо, що встановлена радянськими партизанами індормація про А. Бруцького, як підрайонного провідника ОУН, була достовірною [1, с. 152].

Звичайно, траплялися випадки, що агентурні розробки радянських партизанів Рівненщини «провалювалися». Так, 
партизан С. Лясковець, вступивши у повстанський відділ «Яреми» (Н. Семенюк), організував змову проти останнього, проте справу до кінця він не довів через «нестриманість» учасників таємного плану, яких розкрили та розстріляли [15, арк. 116].

Контррозвідка партизанів Рівненщини відігравала також важливу роль у боротьбі з українськими повстанщями, адже знешкоджувала їх агентуру. Зокрема, вона виявила трьох бандерівських агентів - С. Сидорука, I. Сидорчука i Ф. Марчука, які вступили у РПЗ № 2 у квітні 1943 р. і мали за мету ліквідувати командира з'єднання I. Федорова. Проте змову викрили, а її учасників розстріляли [17, арк. 32; 21, с. 170-172; 27, арк. 15]. У грудні місящі 1943 р. у РПЗ ім. Щорса вступили I. Микуцький, житель села Хіночі Володимирецького району, та Н. Ботаревич, санітарка відділу «Кори». У перші дні свого перебування партизанська контррозвідка викрила їх і встановила, що вони мали завдання заручитися довірою в з'єднанні та при вдалому випадку, знищити командування. Після допиту їх було розстріляно [36, арк. 52].

Попри те, що радянські партизани переважали упівців в озброєнні й чисельності підрозділів, вони гірше знали місцевість і володіли значно меншою підтримкою місцевого населення. Через це складність боротьби із націоналістами зростала. «І націоналістами воювати гірше, ніж із німцями, процес бою з ними легший, але до бою з ними важче, вони хитріші, й у них прекрасна конспірація. Конспірації у них партизанам можна було б підучитися, - згадував після війни начальник штабу РПЗ №1 М. Григор'єв, багатьох своїх людей засилають у наші ряди, вони всіх знають. Знають, хто командує, хто очолює з'єднання. У загоні Місюри, там у них є націоналісти» [38, арк. 11].

Повстанська агентура була також у загоні ім. Кармелюка. На це вказував М. Григор'єв, згадуючи про одного бійця, якому таланило залишатися неушкодженим після нападів бандерівців: «Всіх, хто попався, убивають, а його не убивають, а через 3 - 4 дні ми робимо рейд у відповідь, заганяємо націоналістів подалі та в Трипутн[я] [Дубровицького району] зустрічаємо цього самого хлопця. Звідки ?» [38, арк. 12]. 
Хоч повстанці мали менше досвіду та кваліфікованих кадрів для розвідувальної й агентурної розробки ворожих сил, вони також «вмонтовували» своїх агентів у радянські партизанські загони. Відомо, що один із них проник у травні 1943 р. у загін ім. Богуна. Вичікувавшш слушний момент, він застрелив командира розвідки та двох партизанів. Проте при втечі упівця спіймали та вбили [4, с. 20; 28, арк. 3 зв.].

Траплялися випадки, коли бандерівська розвідка досягала значних результатів у боротьбі із червоними партизанами. Варто згадати, що повстанці проводили військові вишколи для жінок, аби ті виконували військово-розвідувальні завдання. Їхня перевага полягала у тому, що вони викликали меншу підозру та могли легше проникнути у вороже середовище. Так, на початку листопада 1943 р. під час дислокації радянського партизанського загону у с. Вичавки Демидівського району, ройова Н. Кашперук, провівши розвідку, підрахувала їх чисельність та озброєння i повідомила про це через місцевого десятника станичному ОУН В. Дем'янчуку [2, арк. 11-12, 20 та зв.]. Упівці також затримали розвідку радянських партизанів і довідалися, що у них в загоні перебуває 127 осіб, які мають непогане озброєння і мають намір перейти р. Стир та йти до Дубна.

У ніч 32 на 3 листопада українські повстанці організували напад на червоних партизанів силою боївок «Тараса», «Байди», «Гонти», відділу самооборони та трьох вишкільних сотень № 7 (командир - О. Зозуля («Вихор»), № 8 (командир - О. Льопа («Вербовий кущ», «Чабан»)) і № 9 (командир I. Соловей («Діброва», «Драгун») із новосформованого куреня № 3 «Наливайка» (Т. Вівчарук), що дислокувався у с. Хрінники - Вербень того ж району. У результаті нападу загін радянських партизанів втратив більшу частину особового складу: 20 осіб вбиті, 50 потрапили в полон. Повстанці зазнали мінімальних втрат - 3 особи загинули [3, арк. 2627, 32, 59-60;8, арк. 16-17, 20 ; 19, арк. 230].

Висновки. Таким чином, розвідка, контррозвідка й агентура рівненських радянських партизанських з'єднань відігравала важливу роль у протистоянні з українським 
повстансько-підпільним рухом на терені Рівненщини під час німецької окупащії. Унаслідок того, що українські націоналісти мали добру конспірацію, радянські партизани у боротьбі із ними переважно використовували агентурну розвідку, оскільки вона могла надати значно більші результати, ніж бойова. Проте тривалий час їі становлення не дав можливості червоним партизанам використати всі очікувані від неї переваги. Вона почала активно застосовуватися лише наприкінщі 1943 р., коли до РПЗ № 1 прибула опергрупа НКДБ УРСР «Розгром». Попри це, діяльність останньої також мала мінімальні результати, оскільки ї̈ повноцінній роботі завадили організаційно-кадрові проблеми у створенні агентурних позицій в повстанському підпіллі та відділах. Разом із тим цей аспект діяльності чекісти компенсували заходами з ліквідації націоналістичних осередків чи окремих підпільників.

Варто відзначити, що українські повстанці попри те, що мали менше кваліфікованих кадрів для створення агентури у ворожому середовищі, мали власних агентів і розвідників, які проникали у радянські партизанські загони. Проте у зв'язку із вказаною вище причиною результати повстанської розвідувально-агентурної діяльності були меншими у порівнянні з радянськими партизанами.

1. Антонюк Я. Український визвольний рух у постатях керівників. Волинська та Берестейська області (1930-1955) / Я. Антонюк. - Львів ; Торонто : Літопис УПА. - 1069 с. - (Літопис УПА - Бібліотека; Т. 13).

2. Архів Управління Служби безпеки України у Рівненській області (далі - АУСБУ у Рівненській області), ф. Основних справ, спр. 277, 46 арк.

3. АУСБУ у Рівненській області, ф. Основних справ, спр. 18133, 118 арк.

4. Бегма В. Злочини німців і народна боротьба на Рівненщині / В. Бегма. - К.; Х. : Українське державне видавництво, 1945. - 35 с.

5. Веденєев Д. Меч і тризуб. Розвідка та контррозвідка руху українських нащіоналістів та УПА. 1920-1945. / Д. Веденеев, Г. Биструхін. - К. : Генеза, 2006. - 408 с.

6. Веденеев Д. Радянські спецслужби в Україні в роки Другої світової війни / Д. Веденеев // Україна у 
Другій світовій війні: погляд з XXI століття. Історичні нариси у двох книгах. Книга друга. - К.: Наукова думка НАН України, 2011. - С. 279-310.

7. Веденєев Д. Розвідувально-диверсійна та контррозвідувальна діяльність органів державної безпеки за лініею фронту в 1941-1945 pр. (за документами НКВС-НКДБ Української РСР) / Д. Веденеєв // 3 архівів ВУЧК, ГПУ, НКВД, КГБ. - К.; Х., 2014. - № 2 (43). - С. 291-352.

8. Галузевий державний архів Служби безпеки України (далі - ГДА СБУ), ф. 6, спр. 76455 ФП, 60 арк.

9. ГДА СБУ, фр. 60, спр. 28479, т.1, 170 арк.

10. ГДА СБУ, ф. 60, спр. 28479, т.5, 19 арк.

11. ГДА СБУ, ф. 60, спр. 28479, т.6, 22 арк.

12. ГДА СБУ, ф. 60, спр. 28479, т.15, 12 арк.

13. Державний архів Рівненської області (далі ДАРО), ф.. 4054, оп.1, спр. 161, 161 арк.

14. ДАРО, ф. 4054, оп.1, спр. 162, 226 арк.

15. ДАРО, ф. П.1, оп.1, спр. 3, 117 арк.

16. ДАРО, ф. П.1, оп.1, спр. 4, 122 арк.

17. ДАРО, ф. П.1, оп.1, спр. 8, 82 арк.

18. ДАРО, ф. П.1, оп.1, спр. 10, 97 арк.

19. ДАРО, ф. Р-30, оп. 2, спр. 16, 285 арк.

20. Кентій $A$. Війна без пощади та милосердя. Партизанський фрронт у тилу Вермахту (1941-1944) / А. Кентій, В. Лозицький. - К.: Генеза, 2005. - 408 с.

21. Кізя Л. Вирушали в похід партизани. Документальна повість / Л. Кізя. - К.: Політвидав України, 1972. - $282 \mathrm{c}$.

22. Курас И. Штаб непокоренных (Украинский штаб партизанского движения в годы Великой Отечественной войны) / И. Курас, А. Кентий. - К.: Политиздат Украины, 1988. - 329 c.

23. Мищенко Г. Задача особой важности (Партизанская разведка 1941-1945 гг.) / Г. Мищенко, Г. Мигрин. К. : Вища школа, 1985. - 205 с.

24. Органы государственной безопасности СССР в Великой Отечественной войне. От обороны к наступлению: 1 июля - 31 декабря 1942 года. Сборник документов / [авт.-сост.: В. Ямпольский, В. Антонов, И. Белик и др.]. - М. : Русь, 2003. - Т.3. - Кн.2. - 700 с.

25. Органы государственной безопасности СССР в Великой Отечественной войне. Великий перелом: 1 июля - 31 декабря 1943 года. Сборник документов / [авт.-сост.: В. Ямпольский, В. Антонов, И. Белик и др.]. М.: Русь, 2008. - Т.4. - Кн. 2. - 809 с. 
26. Трофьимович $B$. Боротьба за терени впливу між рівненськими радянськими партизанськими з'еднаннями й УПА (1943-1944 рр.) / В. Трофимович, А. Сухих // Військово-науковий вісник Нащіональної академії сухопутних військ імені гетьмана Петра Сагайдачного. Львів: АСВ, 2017. - Вип. 27. - С. 135-150.

27. Центральний державний архів громадських об'еднань України (далі - ЦДАГО України), ф. 1, оп. 22, спр. 508, 25 арк.

28. ЦДАГО України, ф. 68, оп.1, спр. 3, 56 арк.

29. ЦДАГО України, ф. 68, оп.1, спр. 37, 4 арк.

30. ЦДАГО України, ф. 69, оп.1, спр. 1, 143 арк.

31. ЦДАГО України, ф. 69, оп.1, спр. 3, 112 арк.

32. ЦДАГО України, ф. 69, оп.1, спр. 7, 104 арк.

33. ЦДАГО України, ф. 69, оп.1, спр. 9, 11 арк.

34. ЦДАГО України, ф. 70, оп.1, спр. 1, 193 арк.

35. ЦДАГО України, ф. 70, оп.1, спр. 6, 175 арк.

36. ЦДАГО України, ф. 85, оп.1, спр. 1, 197 арк.

37. ЦДАГО України, ф. 166, оп.2, спр. 93, 3 арк.

38. ЦДАГО України, ф. 166, оп.3, спр. 71, 106 арк.

Надійшла до редколегії 05.09.2017 р.

Рецензент: В.В. Трофимович, доктор історичних наук, професор, Національна академія сухопутних військ імені гетьмана Петра Сагайдачного, м. Львів.

\section{Sukhykh Andrii}

THE INTELLIGENCE, COUNTERINTELLIGENCE AND SECRET SERVICE OF RIVNE SOVIET PARTISAN UNITS IN STRUGGLE WITH OUN (B) AND UPA (1943-1944)

In article based on archival materials for the first time had considered questions of the intelligence, counterintelligence and secret service of soviet partisan units that had been subordinated to the Rivne regional headquarters of partisan movement in struggle with Ukrainian rebel movement in Volyn. The secret service and counterintelligence of task force NKGB Ukrainian SSR «Rozgrom» that is arrived in Rivne partisan union № 1 are analyzed. It is shown that Ukrainian rebels attempted to created agents' position in Rivne soviet partisan units.

Keywords: OUN, UPA, UShPR, RPZ № 1, RPZ № 2, task force NKGB Ukrainian SSR «Rozgrom», intelligence, agency, soviet partisan, Ukrainian rebels 